\title{
Governing the Poor: Evidence from New Zealand's Tax and Welfare Systems
}

\author{
LISA MARRIOTT
}

\begin{abstract}
This study examines five situations in New Zealand where individuals receiving welfare benefits receive more punitive treatment than other citizens. Comparison to tax evaders, tax debtors and taxpayers in general is made throughout the article to highlight the disparities that result from regulatory processes that govern the poor. A neoliberal paternalist perspective is evoked to highlight the different treatments of those who are more or less privileged in society. This framework provides visibility to recently introduced market logics, use of surveillance, increased obligations associated with welfare receipt and increased use of the penal system to punish those who offend against the welfare system. The study draws attention to the punitive outcomes that arise from modern-day governance of the poor.
\end{abstract}

This article examines a number of ways in which New Zealand's regulatory environment governs the poor and, in particular, those who are recipients of financial assistance from the state. The punitive treatment of those who have less in society is highlighted throughout the study by undertaking a comparative analysis, as appropriate, with the treatment of tax debtors, tax evaders or taxpayers in general.

The research investigates five areas where regulation results in a harsher outcome for those who are receiving welfare assistance from the state, as compared to those who are not. The five areas are: the justice system's treatment of those who engage in tax evasion and those who engage in welfare fraud; the ways in which tax debts and welfare debts are collected; legislation that provides for the partners of welfare fraudsters to be prosecuted and be liable for the debt generated by their partner; asset seizures of those with welfare debts and tax debts; and the different definitions used for serious hardship in relation to welfare debtors and tax debtors.

It has been established in prior literature that the poor are likely to receive more punitive treatment across a range of spheres in society, most commonly in the justice system. This study builds on this literature, with examples from the justice system, as well as other situations where those who are receiving welfare assistance are singled out for either dissimilar or special levels of governance in New Zealand society. The analytical framework of neoliberalism and new paternalism is evoked to examine the tools of poverty governance used in New Zealand. These frameworks also make visible the privileged treatment afforded to the wealthy alongside the punitive treatment of the poor. In addition, they are used as a platform to illustrate how extant narratives can restrict opportunity for change.

The article commences in the next section with a brief outline of the literature on the different treatments of "white-collar" and "blue-collar" criminals at various stages of the justice system. The purpose of this is to set the scene for the data presented in section two and the analysis in section three. The section also provides an outline of the literature pertaining to governance of the poor, in order to highlight this influence within the five illustrative examples provided in 
section two. In section one, in addition, neoliberalism and paternalism are introduced. Section two has five subsections, each of which outlines an area where those receiving welfare assistance are treated differently than other New Zealanders. The problem is analysed further in section three, with reference to the literature, and the article's concluding comments made in section four.

\section{Prior Studies}

This section has two aims. First, it provides a brief outline of the literature on the discrimination against those who are poor, with a particular focus on the justice system. The punitive treatment of those who are the least advantaged in society has been most visible in relation to criminal activity. There is a well-developed literature that reveals that welfare fraudsters are subjected to a greater degree of punitive treatment. This study expands on this literature by highlighting a number of other, noncriminal, areas where governance of the poor results in detrimental outcomes for this group. Examples are provided in the second part of this section with reference to the influence of neoliberalism and paternalism. Reference to governance in this study concerns the way in which the New Zealand government uses the powers given to it by its citizens. $^{1}$

\section{Different treatments of poor and wealthy criminals}

Issues relating to the preferential treatment of white-collar criminals were given greatest visibility by Edwin Sutherland well over 60 years ago. ${ }^{2}$ Sutherland's key contribution came from his suggestion that individuals committing white-collar crime were likely to have greater power, greater resources and greater influence, all of which were likely to impact on how they were treated in the justice system. ${ }^{3}$ Subsequent studies have highlighted the preferential treatment received by those who engage in white-collar crime. ${ }^{4}$

Those who are receiving assistance from the state in the form of traditional welfare benefits, such as those who are unemployed or sole parents, and who commit financial offences associated with welfare assistance, have been a particular target for punitive treatment. For example, in Australia "a sentence of imprisonment is generally considered to be the starting point by the courts in social security fraud cases." This is despite the fact that financial offending undertaken by the wealthy is "often much greater than that of common criminals." 6 Research from New Zealand concurs with this finding, showing that welfare fraudsters are more likely to be given a custodial sentence for a lower level of financial offending than tax evaders. $^{7}$

A range of studies has asked respondents to rank crimes in order of seriousness. These studies typically find that tax evasion or other forms of financial fraud are considered to be less serious then welfare fraud. ${ }^{8}$ An Australian Institute of Criminology study found that individuals perceived welfare fraud as more serious than tax evasion or Medicare (health) fraud, despite the fact that the funds presented in the welfare scenario were only 20 percent of the tax and Medicare scenarios. ${ }^{9}$ A further report by the Australian Institute of Criminology on this same study shows that individuals prefer longer prison sentences for welfare fraud than tax evasion, and greater use of fines for tax evasion than for welfare fraud. ${ }^{10}$ Similar findings are reported in New Zealand. ${ }^{11}$ These reports are representative of the majority of studies that find that white-collar crime, including tax evasion, is treated as less serious than other financial offending of similar value. ${ }^{12}$

Journal of New Zealand Studies NS27 (2018), 110-129

https://doi.org/10.26686/jnzs.v0iNS27.5179 
There are multiple potential reasons for differences in attitudes towards welfare fraud and tax evasion. One option is that tax evaders are not giving their legislated contributions to the state, while welfare fraudsters are taking more than their legal entitlement from the state. Research also suggests that attitudes to tax evasion are more favourable, as those in receipt of welfare "should be grateful that they are getting assistance from the Government and they should not try to take more than they are entitled to' and 'taxpayers are already contributing to society, whereas those on welfare are not". ${ }^{13}$

\section{Poverty governance, neoliberalism and new paternalism}

Research increasingly suggests that the poor will be discriminated against in many private sector transactions. These examples include, but are not limited to, the housing market, retail transactions and the financial industry. ${ }^{14}$ Excess punitiveness can also be seen in the public sector, as state sanctioned governance of the poor has the potential to exacerbate the treatment that has positioned the least advantaged in their place in society. The outcomes of the governance of the poor may result in reduced opportunities for social and economic advancement and "active exclusion from the personal benefits of social integration and community." 15

\section{Neoliberalism}

The lenses of neoliberalism and paternalism are used to frame the examples of poverty governance outlined in this study. Neoliberalism emphasises the role of the individual and "is an effort to extend the reach of market logic, to apply it as an organizing principle for all social and political relations." 16 Thus, neoliberalism departs from the collective view of society and accentuates personal freedom in decisions and their concomitant outcomes. Through this lens, market-based outcomes are desirable and the role of the state is to facilitate efficient markets. It is acknowledged that pure neoliberalism would see a free market system in all parts of society, resulting in the absence of a welfare system. Thus, reference to neoliberalism in this study is not intended to suggest full adoption of neoliberal policies; instead, it refers to the introduction of some of the concepts that underpin neoliberalism.

While neoliberalism may be thought of as a policy framework, as an ideology or as governmentality, this study uses the term primarily from a governmentality perspective. ${ }^{17}$ Quoting Wendy Larner, "the most influential post-structuralist theorization of neo-liberalism is that associated with the neo-Foucauldian literature on governmentality." 18 Reference to governmentality sought to "draw attention to a certain way of thinking and acting embodied in all those attempts to know and govern the wealth, health and happiness of populations." 19 Thus, the first aim of this study is to provide a range of evidence to show greater governance of the poor resulting from neoliberalism.

Of particular relevance to the current study is Joe Soss, Richard Fording and Sanford Schram's critique of the position that citizens "are 'taxpayers' who have a contractual right to expect efficient institutional actions that produce a good return on their investment." 20 The authors go onto suggest that the "competent and self-reliant market actor-working, investing, making consumer choices, and demanding a good return - is made synonymous with the good citizen." 21 Of necessity, there is also a "bad citizen," who, under a neoliberal lens, is the individual who does not participate in these activities. 
Morrow claims that welfare states-paid for by contributing taxpayers and utilised by noncontributing beneficiaries - are associated with "significant and dangerous general tendencies to ignore the distinction between rules of just conduct and administrative commands." 22 John Morrow captures this concept when writing that welfare states "compel those who have participated successfully in the market to contribute to the support of those who either make no effort to engage in socially useful exchanges or have been relatively unsuccessful in their attempts to do so." ${ }^{23}$ The danger to society is noted as minimising incentives for productivity and entrepreneurship.

The adoption of neoliberal ideas is evident in New Zealand from the mid-1980s. Prior to this time, New Zealand was an example of a typical welfare state, with a focus on "social responsibility and the mutuality of social risk." 24 Then, the 1980s saw the adoption of what was commonly considered as an experimental approach: reducing the function of the state, increased focus on free markets, deregulation and privatisation, combined with "an ideological commitment to the individual rather than to society, and a complementary panoply of values." 25 While government regulation was reduced, so was the concept of state involvement in producing particular welfare outcomes. ${ }^{26}$

Morrow notes the "strong strand of moralism" in contemporary neoliberalism, and Nicholas Rose and Peter Miller observe the move from welfarism to neoliberalism "at the level of moralities, explanations and vocabularies." ${ }^{27}$ All of these are visible in New Zealand from around three decades ago. Ruth Richardson, Minister of Finance, viewed benefit cuts in the early 1990s as "a statement about the types of lives people should be encouraged to lead, about the types of activities that should be more highly valued, about personal responsibility and integrity." She argued that discussions on the affordability of the welfare state had assumed that "the welfare state is a "good thing." 28 Upon elaborating on the types of citizens that were seen as less desirable, she contended that the benefit system created strong incentives for people to "alter their circumstances, either to become eligible for a benefit or to remain eligible for a benefit," which they would remain on indefinitely; that the extant system resulted in the state "subsidising bad choices"; and that the Domestic Purposes Benefit (DPB): 29

affected social behaviour in a way that was to have deep and undesirable consequences. It substantially altered the incentives and moral sanctions surrounding human relationships and child-rearing. . . . The DPB reduced the expected financial cost; just as important, it reduced the cost of social disapproval. For women, the DPB also meant they had less at stake when investing in a relationship. For both men and women who were casual about relationships and careless about the consequences in the form of any child that might follow, personal irresponsibility was sanctioned. ${ }^{30}$

One focus of the neoliberal reforms was the expectation that individuals would take responsibility for their own actions. Negative impacts from such actions were acceptable, but only to the extent that these did not impact on other individuals. As noted by Morrow, "neoliberals do not regard structural sources of disempowerment such as restricted access to educational or material resources as breaching this condition: harm only occurs when an individual's rights are infringed by an identifiable assailant." 31

The benefits to be gained by the privileged minority are evident from neoliberal reformsreduced tax rates that are of greatest benefit to higher income earners and corporations; erosion 
of the protection of trade unions; and reduced redistribution to assist those who are least well off in society. Its appeal is evident in the "lure of the language of liberal theory with its emphases on individualism, ownership, choice, flexibility, and competition that mask the grim realities of the restoration or reconstitution of naked class power." 32

Neoliberalism requires both the political and social spheres to be dominated by market concerns and organised by "market rationality." 33 There are multiple examples of an increasingly market-based approach to welfare provision in New Zealand. Examples include an "investment approach" to welfare provision and the introduction of "social bonds" for funding expenditure programmes. Both of these examples were proposed around 2013. The first social bond is in operation, which aims to get more people with mental health issues into employment. ${ }^{34}$ The investment approach was introduced for welfare and subsequently expanded to other government activity that incurs costs, such as social housing.

The increased individualisation of welfare provision is perhaps most evident in the explicit investment approach of the welfare agency, the Ministry of Social Development (MSD), in New Zealand. The 2016 Strategic Plan noted:

underpinning welfare reforms is an investment approach that is ensuring we invest our support where it will make the biggest difference. Through this approach we are focusing on people most at risk of long-term welfare dependency by investing more up front to help them get into work sooner. ${ }^{35}$

The investment approach has positive components, but in its initial form the proposals were particularly punitive. The market logics informing the approach are visible in the use of an actuarial valuation to understand the long-term liability of the welfare system. The aim is to use actuarial calculations to identify groups of people who require "more specialised interventions in order to find and stay in work." 36 These calculations assess an individual's future contribution to society as compared to the assessment that they will remain a "liability" to the state over his or her lifetime. This creates a situation where "the value of an individual unit of human capital is her future cash flows." 37 As at 2018, four annual actuarial reports had been finalised, which measured the "forward liabilities of the welfare system". ${ }^{38}$ The last of these was published in 2017. The language used in the reports refers to people as liabilities; attaches monetary values to these liabilities; and calculates a return on investment for certain people and programmes. ${ }^{39}$ However, the future of the investment approach is uncertain as a result of a change of government in New Zealand in late 2017. While little has changed at the present time, the focus of the new government is on investing for social wellbeing, but how this will be reflected in practice is unknown at the present time.

A further example of the investment approach is visible in the introduction of social bond schemes. Social bonds provide for private and not-for-profit entities to partner with the Government to deliver social policy outcomes. Where agreed results are met, the investor will regain their investment with an agreed return. However, returns are dependent on results and where results are not met, no return is paid and the investment may be lost. While social bonds are promoted as an effective way of funding public programmes, they have been described as "a new attempt to manage the roles of the state, the private sector, and the charitable sector under neoliberalism." 40 


\section{Paternalism}

The paternalist view is derived from the traditional parental relationship, where the state has greater capacity to know what is best for its subjects. Moreover, the state has a "moral obligation to act on this knowledge." ${ }^{\prime 1}$ Using the parent-child analogy, Soss, Fording and Schram outline how such paternalism provides for the state (parent) to use legitimate authority to "direct and supervise"; to deny what the subject (child) wants; to impose what the subject (child) resists; and to punish what the subject (child) chooses to do. ${ }^{42}$ Paternalism in relation to social policies is described by Lawrence Mead as "policies aimed at the poor that attempt to reduce poverty and other social problems by directive and supervisory means." 43 While helping those in need, they dictate certain behaviours, which are enforced through supervision and penalties for noncompliance. It is notable that the poor are the objects of paternalism. ${ }^{44}$

Soss, Fording and Schram adopt the term "new paternalism" to inform their discussion on poverty governance. ${ }^{45}$ They suggest that this view allows insight into the premise that the poor lack the competence to manage their own affairs, lack the discipline needed to engage in appropriate behaviours, have insufficient incentive to act in their own interest, and need direction to live in a form that is desired by the state. Such views are visible in the writings of Mead, who claims that:

the main problem with the welfare state is its permissiveness, not its size. Today poverty often arises from the functioning problems of the poor themselves . . . the social programs that support the needy rarely set standards for them. Recipients seldom have to work or otherwise function in return for support. If they did, the evidence suggests they would function better. ${ }^{46}$

New paternalism emphasises the obligations of citizenship. The poor, and particularly those who receive welfare assistance from the state, are targeted as a convenient sample of those who do not fulfil their citizenship obligations. Mead supports paternalism, claiming that "the answer is simply that social programs have failed partly because they expect too little of their recipients, not too much, and there is evidence that clearer standards would improve functioning," and that "it is precisely the groups who do not work regularly yet are not clearly disabled - unskilled men and welfare mothers with children-who have been the crux of the social problem." ${ }^{47}$ Mead continues to outline the obligations of adults: they should work in available jobs unless aged or disabled; they should support their family; they should be sufficiently educated to be employable; they should be fluent and literate in English regardless of where they were born; and they should be law-abiding. ${ }^{48}$ Thus, the boundaries of the "good citizen" are established.

New paternalism directs that, for the good of society, the state has a role in controlling the behaviours of the poor. Moreover, this control can be exerted by influence of the income available to the poor, whereby the provision of financial support comes with requirements to behave in ways determined to be acceptable. While compliance is ostensibly voluntary, noncompliance will result in withdrawal of financial support. Soss, Fording and Schram's critique observes that control may take the form of directive social programmes, increased surveillance, and removing "disruptive individuals through incarceration." 49 These three examples are increasingly used in New Zealand, as outlined below. 
This discussion is not intended to disregard the reciprocity that is implicit within the welfare system or the value of the welfare system. Instead, the aim is to highlight the changes in reciprocity that have evolved to become more punitive. From 1 April 2016, many welfare benefits in New Zealand were increased. However, the increases came with associated obligations in addition to the extant requirements already in place. Recipients must advise Work and Income New Zealand (the government department responsible for delivery of financial assistance and employment services) if they travel overseas, start or finish studying, or are admitted to or discharged from hospital, among a range of 11 "change of circumstance" obligations. ${ }^{50}$ Most people on Jobseekers Support are expected to look for work of at least 30 hours per week. There are eight further obligations, including taking "any offer of suitable fulltime, part-time or temporary work, or work that is seasonal or subsidised"; attending any suitable job interview as requested; attending interviews with Work and Income as required; taking part in "any other activities that we refer you to, such as attend any job training courses, seminars, work experience or work assessments (including rehabilitation, but not medical treatment) that will improve your work readiness or help you get work" $" 51$; and informing Work and Income of how these work obligations are being met "as often as we reasonably require." 52 Where the recipient has a partner, the partner may also be obliged to meet work obligations. Where suitable work has not been accepted "without a good and sufficient reason," benefits will be reduced by up to half (where the recipient has dependent children) or stopped (if there are no dependent children) for 13 weeks. Missing other work obligations will also result in punishments, including benefit withdrawal.

More punitive measures have also been introduced for individuals receiving Sole Parent Support who have a further child while on this benefit. Under the new regime, individuals are expected to look for work when that child is one year old. Where the next youngest child is less than three years of age, the welfare recipient will need to "take practical steps to prepare for work." Where that child is between three and 13 years old, the welfare recipient will be expected to actively pursue part-time work of at least 20 hours per week. Where that child is 14 years or older, the recipient is expected to actively seek full-time employment of at least 30 hours per week and to accept any suitable job that is offered. The assessment that any employment is more desirable than no employment is clearly visible under these arrangements and obligations.

In their critique of paternalism, Soss, Fording and Schram suggest that "the poor are subjected to directive and supervisory governance, not just for their own good, but equally for the good of society and democracy." 53 This is particularly noticeable with reference to Youth Payments in New Zealand. Youth Payments are provided to those aged 16 or 17 who cannot live with their parents and have no other financial support. Youth Payment recipients must be actively involved in full-time education, training or work-based learning. They must attend a budgeting course and work with a Youth Service Provider. For those who require "money management," some of the financial support provided will be in the form of a payment card, which may only be used for goods such as food and groceries. Some youths of 16 or 17 may require assistance in budgeting or other financial tasks. Research from New Zealand suggests that budgeting advice for those on low incomes improves their financial situation. ${ }^{54}$ However, youths receiving the Youth Payment have no autonomy in this decision; instead, attending a budgeting course is a requirement of financial assistance. 
As observed by Vincent Dubois, there is increasing emphasis on increasing control and the use of data matching technologies for this control. ${ }^{55}$ Increased surveillance in New Zealand is visible with increased use of data matching and information sharing. The most recent MSD annual report provides details of information sharing with a number of agencies. Most relevant is information sharing with the tax authority, Inland Revenue, whereby income and employer information for welfare recipients is shared in real time to "detect overpayments and fraud sooner." ${ }^{, 56}$ Since the inception of increased information sharing in 2013 , the programme has led to 970 successful prosecutions, 10,213 benefit cancellations and recovery of $\$ 9.1$ million of overpaid benefits. ${ }^{57}$ It should be noted that "overpayments" are not the same as fraudulently obtained payments. Overpayments may result from a range of nonfraudulent behaviours such as overestimations of entitlements due to underestimations of income.

Increased surveillance is also visible in the 2013 introduction of a "relationship status verification form." 58 This form requires the person seeking a benefit to nominate someone to complete the form, the primary purpose of which is to elicit information on the relationship status of the applicant. The form requires the person completing it to "using your own words, describe the relationship status of the person." 59 The form includes the caveat that providing false information could lead to prosecution, fines or imprisonment.

The punitive treatment of those on welfare extends beyond the conditions attached to welfare receipt and into the justice system. One example that is explored in the next section occurs when welfare recipients commit crimes when in receipt of welfare. Loic Wacquant observes that the "generalised increase of carceral populations in advanced societies is due to the growing use of the penal system as an instrument for managing social insecurity and containing the social disorders created at the bottom of the class structure by neo-liberal policies of economic deregulation and social-welfare retrenchment." ${ }^{60}$ This is evident in New Zealand and is examined in the following section. Wacquant terms this "neo-liberal penality," 61 and it is also visible in the approach of other writers who identify the criminalisation of welfare. ${ }^{62}$ Alongside the use of prison as a punishment for noncompliance with the welfare system, social welfare "reform" and retraction is used alongside welfare provision to communicate the state view of those who are not fulfilling their civic duties.

Commentators have observed that the poor are an easy target for "reform." 63 The poor have few resources, they are typically not well networked, and are usually less organised than wealthier groups in society. In New Zealand, the poor have suffered from the demise of trade unions, ${ }^{64}$ and those who are in receipt of welfare are not typically viewed as worthy of public sympathy in the same way as, for example, children living in poverty. The neoliberal paternalistic approaches to welfare are also visible in more subtle tools, such as the definitions used to determine welfare entitlement or to determine what is a crime. Five specific examples follow.

\section{Discrimination and Governance of those on Welfare}

This section outlines five ways that rules are used, interpreted, or written in such a way that those who are poor receive more punitive treatment than those who are privileged. It starts by briefly outlining three areas that have previously established this outcome. It then provides two new areas that further illustrate how the poor are isolated for special treatment by the state. 


\section{Tax evasion and welfare fraud in the justice system}

As outlined in the previous section, research has established that individuals who may identify as "blue-collar" are likely to be treated differently in the justice system than individuals who identify as "white-collar." This has been established in relation to the treatment of tax evaders and welfare fraudsters in the New Zealand justice system. Over the past decade, numbers of welfare fraud investigations ranged from 7,500 (in 2013/14) ${ }^{65}$ to 26,746 (in 2007/08). ${ }^{66}$ This contrasts with tax fraud investigations which are typically around 1,000 per annum. In most years welfare prosecutions number around 1,000 cases ${ }^{67}$ Criminal prosecutions resulting from tax investigations range from 60 to 80 per annum. ${ }^{68}$

The different treatments of tax and welfare fraudsters are perhaps most evident in the sentencing. Research shows that for average welfare fraud offending of \$76,550, 67 percent of offenders received a custodial sentence. By way of contrast, for average offending of $\$ 229,471$, 18 percent of tax offenders received a prison sentence. This example may be further highlighted with reference to two case studies. It will never be possible to find two identical case studies for comparative purposes, but these two case studies had similar periods of offending and similar financial harm resulting from the crimes. As such, they provide an effective illustration of some of the different outcomes that result from tax offending and welfare offending.

In 2006, Wayne Patterson ${ }^{69}$ was investigated, prosecuted and convicted of welfare fraud of $\$ 3.4$ million. He had previous convictions in other countries for similar offending. At the time of the conviction Patterson was sentenced to eight years and nine months in prison. While he was eligible for release in 2008, he was not released at this time as he was subsequently charged with forging a document, which was a letter to the Parole Board indicating that he had been accepted for a job interview. Patterson received a further two years in prison for this offence. His offending is unique in two ways: firstly, in the quantum of the offending - at the time of the prosecution the case was more than ten times the value of the most serious welfare fraud case previously discovered $(\$ 250,000)$; and secondly, the whole amount was repaid-indeed the Crown made a significant gain from the exercise. ${ }^{70}$ Patterson had invested some of the fraudulently obtained funds in Apple shares, and while he contested ownership of these shares, eventually the courts ruled that the Crown was also entitled to these shares, which had increased in value to $\$ 3.3$ million. Thus, $\$ 6.7$ million was repaid to the Crown from Patterson's offending. He was released after serving 10 years in prison.

By way of comparison, Alex Swney engaged in white-collar offending for over a decade. In 2015 , he was convicted of having $\$ 1.8$ million of unpaid taxes,${ }^{71}$ and a further $\$ 2.5$ million in defrauding a publicly funded organisation, of which he was Chief Executive Officer. The fraud was deliberate and involved the creation of 229 fictitious invoices, where the payment was directed to Swney. He was jailed for five years and seven months. At the time of the conviction, the tax remained outstanding and an Inland Revenue media release noted that the department would be working to recover the stolen funds. Swney served 22 months in custody before his release.

What is noticeable about these two cases studies is that they are both serious financial offending of a similar amount. The white-collar offending is higher at $\$ 4.3$ million as compared to the blue-collar offending at $\$ 3.4$ million. In the case of the welfare fraud a harsher sentence was 
awarded, yet all the funds were repaid and further financial recompense was made to the Crown. A lesser sentence was awarded for the tax and financial fraud where none of the funds were repaid. Patterson served 10 years in prison: Swney served less than two.

The relevant mitigating and aggravating factors in the Sentencing Act 2002 for these crimes are the loss resulting from the offence; abuse of a position of trust; previous convictions; previous good character; remorse; or an early guilty plea. Thus, there are factors that apply both for and against the two individuals discussed above. However, none of these mitigating or aggravating factors is sufficient to explain the difference in sentencing outcomes given to the two crimes. While this comparison would not appear to be relevant to a discussion of governing the poor, as neither offender appeared to fit this description, they are included here as they illustrate the different treatments of those who receive welfare and those who do not.

\section{Management of tax debt and welfare debt}

The previous subsection illustrates how tax evaders and welfare fraudsters may be treated differently in the presence of crime. However, differences are also visible when there is no suggestion of crime. This is the second topic used to illustrate how people are treated differently depending on whether they have greater or lesser resources. Research undertaken comparing the policies for debt collection in Inland Revenue and MSD highlights different approaches undertaken by the agencies, despite the conceptual similarity of the debts. Tax debts are created when tax returns are filed but not paid when due. Welfare debts may be generated from overpayments or recoverable assistance loans, both of which are repayable to MSD.

Both agencies can, and do, use instalment arrangements and deduction notices to assist with collection of debt. However, different approaches are visible in relation to both writing off debt and pursuing debt. By way of example, Inland Revenue has wide discretion to write off penalties and interest associated with debt. In addition, it also allows some circumstances in which tax debt may be written off. In 2015/16, \$1.1 billion of tax debt was written off-19 percent of collectable debt. By way of contrast, MSD adopts a less lenient approach to writing off debt, whereby "all monies owed to the Crown are actively pursued and debts remain with each individual until all avenues to recover have been exhausted." "Welfare debt will only be considered for write-off when "all reasonable and practicable avenues of recovery have been exhausted", as there are no legislative provisions for write-offs in the same way as there is for tax owed. ${ }^{73}$ Examples provided by MSD include where the debt is the result of a Ministry error; where a debtor has died and the estate is insolvent or distributed prior to the Crown notifying its claim; where the debtor is insolvent and has been adjudicated bankrupt; or where the Official Assignee has recognised under the No Asset Procedure that the debtor is insolvent with no realisable assets. In 2011/12, \$13.3 million of welfare debt was written off: 1 percent of total debt. $^{74}$

Further evidence of the punitive approach adopted towards welfare debtors is visible in the amount of expenditure incurred by the tax and welfare agencies in collecting outstanding debt. In $2011 / 12$ the cost of debt recovery for welfare debt was $\$ 17.00$ for each $\$ 100$ collected.$^{75} \mathrm{At}$ June 2012, the tax debt recovery cost was $\$ 2.86$ for collecting $\$ 100$ of overdue revenue. ${ }^{76}$

Since 2013, MSD has been working with a number of agencies, including Housing New Zealand, Inland Revenue and the New Zealand Police, to investigate cases of suspected welfare 
fraud. In the time since its inception, 38 joint investigations have identified $\$ 4.5$ million in overpayments, resulting in 24 cancelled benefits and seven prosecutions. ${ }^{77}$ Considerable effort is made to detect and collect debts generated from welfare fraud. A similar approach is not visible with finding and collecting tax evasion. Moreover, MSD are prepared to invest considerable resources in investigating welfare fraud, most of which generates little in the way of return on this investment.

\section{Who is responsible for tax debt and welfare debt?}

The third topic in this section examines amendments made on 7 July 2014 to the Social Security Act 1964 relating to individuals who were convicted of relationship fraud. ${ }^{78}$ The legislative changes resulted in the potential for the partners of those who had been convicted of receiving welfare benefit overpayments as a result of welfare fraud to be jointly and severally liable for the welfare debt generated from the fraud. In addition, the legislative changes allowed for criminal liability for the fraud to be extended to the partner of the person who engaged in the fraudulent activity. The changes require the partners to knowingly benefit from the fraud, but also extend to situations where the partner "ought to have known" they were benefitting. The partner of the beneficiary who has committed the fraud does not need to know the precise amount of the fraud or how the fraud occurred.

The issue with this legislative change is that it isolates a small section of society-welfare beneficiaries and their partners - for separate treatment in the justice system. There have been no attempts to include the partners of those who engage in other forms of financial offending within this extension of liability. This is despite the fact that the partners of those who engage in serious tax evasion or serious financial fraud are likely to benefit to a greater extent than the partners of those who engage in welfare fraud, solely from the average magnitude of such offending.

Section 86AA of the Social Security Act 1964 is the section that introduces recovery from the partner of excess amounts obtained by fraud. On 15 June 2016, an Official Information Act request was made to MSD, asking if any debt had been recovered under new section 86AA. In response to this query, MSD advised that 130 debts had been established under this new section, with collection of $\$ 200,000 .{ }^{79}$

\section{Asset seizure of tax and welfare debtors}

The fourth illustration of different treatments of poor and wealthy people outlines asset seizures. The Tax Administration Act 1994 provides for deductions of tax to be made from payments such as wages or salaries when tax debt exists. ${ }^{80}$ On 15 July 2016, an Official Information Act request was made to Inland Revenue asking for the frequency of such deduction notices over the past five years. Deduction notices are issued to third parties, typically banks or employers, in order that deductions are taken from amounts payable to the debtor. Deductions may be lump sums or instalment arrangements. Thus, deduction notices are a mechanism to seize financial assets. A request was also made for information on the ability of Inland Revenue to seize tangible assets where debtors had defaulted on their payments, and whether this mechanism had been used over the past five years. A similar request was made to MSD. 
Information received on the use of deduction notices from Inland Revenue is outlined in Table 1. As a proportion of debtors, deduction notices were issued to approximately 17 percent of debtors in most years and around 1 percent of all taxpayers.

Table 1: Deduction Notices Issued under Section 157 of the Tax Administration Act $\left(\right.$ 2011-2015) ${ }^{81}$

\begin{tabular}{|l|l|c|}
\hline Year Ended & Notices Issued & \% of Taxpayers \\
\hline 30 June 2011 & 64,025 & $0.915 \%$ \\
\hline 30 June 2012 & 68,501 & $0.979 \%$ \\
\hline 30 June 2013 & 57,395 & $0.820 \%$ \\
\hline 30 June 2014 & 66,126 & $0.945 \%$ \\
\hline 30 June 2015 & 73,013 & $1.043 \%$ \\
\hline
\end{tabular}

Inland Revenue also advise that 36 charging orders in total were applied under section 169 of the Tax Administration Act over the same five-year period. A charging order prevents a debtor from selling the property over which the charging order is placed until the creditor has had the opportunity to seize or sell it to satisfy any outstanding debt.

Inland Revenue advises that there are no provisions that explicitly permit the Commissioner of Inland Revenue to seize assets to assist with debt recovery. ${ }^{82}$ Additionally it notes that as a general creditor who has obtained judgment in the District Court, the Commissioner is entitled to apply for a distress warrant to seize assets under section 85 of the District Courts Act 1947, but that this option has not been used as the Commissioner has other, more cost-effective options available. By way of contrast, MSD reports $\$ 0.58$ million recovered through asset seizures and reparation orders. ${ }^{83}$ The ministry advises that there are "a small number of people that are prosecuted for benefit fraud who have significant assets which could be secured and used to repay their debt." 84 The process for this is that the Ministry can request the seizure of such assets under the Criminal Proceeds (Recovery) Act 2009. However, since 2012, only two such requests have been made.

Information received on the use of deduction notices from MSD is outlined in Table 2. The ministry advises that the decision to issue a deduction notice is made only after all other practicable steps have been exhausted and with consideration of avoiding significant hardship to the client. As a proportion of welfare recipients, deduction notices were issued to 7-12 percent of welfare recipients, as compared to around 1 percent of taxpayers. However, many welfare debtors will not be employed or have financial assets from which deductions may be claimed. 
Table 2: Deduction Notices Issued under Section 86A of the Social Security Act 1964 $\left(\right.$ 2011-2015) ${ }^{85}$

\begin{tabular}{|c|c|r|}
\hline Year Ended & Notices Issued & \multicolumn{2}{|c|}{$\begin{array}{c}\text { \% of Welfare } \\
\text { Recipients }\end{array}$} \\
\hline 30 Dec 2011 & 20,275 & $6.76 \%$ \\
\hline 30 Dec 2012 & 25,733 & $8.58 \%$ \\
\hline 30 Dec 2013 & 33,425 & $11.14 \%$ \\
\hline 30 Dec 2014 & 35,115 & $11.71 \%$ \\
\hline 30 Dec 2015 & 36,269 & $12.09 \%$ \\
\hline
\end{tabular}

It is notable that Inland Revenue does not seize assets from debtors. The department advises that it has more efficient mechanisms to collect debts. However, the value of debts that are written off suggests that there is capacity to supplement these mechanisms with other tools, such as asset seizures. It has been noted above that Inland Revenue appear considerably less willing than MSD to actively pursue its debtors and the approach towards asset seizures is consistent with the overall approach to debt collection.

\section{Serious hardship}

The final topic examined in this study is the different definitions of, and approaches to, serious hardship when tax and welfare debts exist. These debts do not necessarily arise from crimethe majority are legitimate debts where tax returns have been filed but taxpayers are unable to pay the tax due, or individuals have received loans from MSD to meet emergency spending requirements and are having difficulty repaying those loans.

\section{Serious hardship for tax purposes}

Under the Tax Administration Act 1994 (TAA) the Commissioner of Inland Revenue must collect the highest net revenue that is practicable within the law, having regard to: available resources; the promotion of compliance by all taxpayers; and the compliance costs incurred by taxpayers. ${ }^{86}$ Notwithstanding this objective, recovery of tax must not place the taxpayer in a position of serious hardship or be an inefficient use of Inland Revenue resources. ${ }^{87}$ There are provisions within the TAA for taxpayers to apply for financial relief, such as when recovery of their tax debt will place them in a position of "serious hardship." ${ }^{88}$ Not all tax debt will be eligible for financial relief, even when collection will place the taxpayer in a situation of serious hardship, such as some tax evasion activities. ${ }^{89}$

Serious hardship is defined in the TAA as including significant financial difficulties that arise where taxpayers or their dependants have a serious illness, such that the taxpayer would be unable to meet minimum living expenses estimated according to normal community standards of cost and quality; or the costs of medical treatment for an illness or injury of the taxpayer or their dependant; or the cost of education for the taxpayer's dependants; or other factors that the Commissioner thinks relevant. ${ }^{90}$ The TAA also makes it clear that compliance or noncompliance with tax obligations is not a factor to be taken into consideration when the decision on financial relief is taken. ${ }^{91}$ 


\section{Serious hardship for welfare purposes}

Historically, section 27 ZG of the Social Security Act 1964 contained provisions that allowed for debt and other relief in cases of serious hardship. However, this section was repealed in 1992 and no similar provision has been enacted subsequently. Thus, unlike with taxation, there are no legislative provisions that provide for assistance when debtors are suffering from serious hardship. As the legislation does not provide for serious hardship, there is no definition of this term in the Social Security Act 1964. Guidance on the treatment of debtors suffering from serious hardship therefore needs to be sought from government documents.

Where Inland Revenue may remit or write-off penalties, interest and/or tax debt in cases of hardship, MSD will take hardship into account by "negotiating realistic repayment rates with debtors so that significant hardship is not caused," 92 while also noting that "hardship does not necessarily preclude recovery." "In "exceptional circumstances," payment may be temporarily deferred until a person's financial circumstance improves in order that significant hardship is not caused. ${ }^{94}$

The absence of legal protection of welfare debtors from serious hardship, compared to that for taxpayers, results in different outcomes. Welfare debtors are subject to the discretion of public officials in relation to any concessionary treatment they receive. Moreover, the absence of provisions to write off debt results in a situation where the debt cannot be written off, unlike the procedures with regard to tax debt.

\section{What is the problem?}

The issue is captured effectively by Schram, Soss, Fording and Linda Houser when they write that "welfare policies for the poor have been redesigned in recent years to reflect the idea that the state has a legitimate interest in ensuring that socially marginal groups practice appropriate behaviors." 95 However, the problem goes beyond the punitive governance of the poor and extends to privilege the wealthy. All examples provided above serve not only to disadvantage those in society who have the least, but also to act to benefit those who have the most. Policies towards investigations, prosecutions and sentencing of those who engage in tax evasion are less punitive than those who engage in welfare fraud. Processes for debt collection and debt management advantage those who have tax debts when compared to those who have welfare debts. The partners of those who engage in tax evasion are not pursued for the debts of their partner and are not potentially liable for prosecution where they have benefited from the crime, unlike the partners of those who engage in welfare fraud. While asset seizures are not frequently used, MSD has historically used this avenue to collect welfare debts in a small number of cases, while Inland Revenue has not. Moreover, those with tax debts will be afforded greater leniency than those with welfare debts if they are in a position of serious hardship.

The examples of regulation and policy tools outlined in the previous two sections highlight the extent to which the state is involved in ensuring compliance, particularly through the use of sanctions as tools to "teach self-discipline to recipients" of welfare. ${ }^{96}$ The new paternalism approach to welfare creates sanctions when rules are not followed. This is visible in the data outlined above, showing that noncompliance in the welfare system will be punished more harshly than financially equivalent noncompliance in the tax system. Recent figures report over 10,000 benefit cancellations where overpayments have occurred. ${ }^{97}$ However, there are a 
number of legitimate reasons why overpayments may have been made that are unrelated to fraudulent behaviour.

The welfare system in New Zealand is aimed at regulating and, where necessary, disciplining the poor who are in need of support from the state. This is a departure from its historical focus, which was redistribution and ensuring that individuals had the resources to belong and participate in society. ${ }^{98}$ The "investment approach" of the previous New Zealand government adopted a punitive attitude to welfare recipients. It served to reinforce what Schram, Soss, Houser and Fording title an "object lesson," "instructing low-income populations that even the meanest wages and work conditions are better than the shameful status of the "welfare poor." 99 Jobseekers Support essentially requires welfare recipients to apply for low-income work in order that they relocate from being a less deserving welfare recipient to a desirable working taxpayer.

Wacquant links changes in welfare and the justice system, suggesting that increasing emphasis on work readiness alongside increasing use of prison as a punishment for noncompliance with the welfare system is designed to discipline the poor. ${ }^{100}$ Wacquant further observes that "at the lowest rung of the social ladder, incarceration serves to physically neutralise and warehouse the supernumerary fractions of the working class and in particular the dispossessed members of stigmatised groups who persist in entering into 'open rebellion against their social environment." 101 In New Zealand, those who offend against the state while receiving welfare assistance may expect to be treated more harshly than those who, to adopt Wacquant's representation, are not on the lowest rung of the social ladder.

The discussion in the previous section on welfare eligibility returns to the concepts of "good" and "bad" citizens. Not all those who receive financial assistance from the state are treated as deserving or undeserving. Conceptually, those receiving the state pension are the same as those receiving other forms of income support. However, those who receive welfare assistance in the form of the universal state-provided pension are not subject to the same tests, surveillance, reporting or control as those who receive state assistance in the form of Sole Parent or Jobseekers Support. To the extent that reciprocal arrangements exist between the recipient and the state, or the recipient and the taxpayer who is the ultimate funder of the benefit, these are not equivalent when pension recipients and other welfare benefit recipients are contrasted.

The contrasting treatment of the two groups (pensioners and "other" welfare recipients) is evident. Pensions are received by those aged over 65, who may or may not need the financial assistance: recipients are not required to demonstrate need to qualify for the pension as it is not means-tested. By way of contrast, Sole Parent Support or Jobseekers Support are for people who have no financial support for their children or are unemployed, and qualification is determined by need for the assistance. The different treatment of these two groups within the welfare system highlights their positions as "deserving" (pensioners) and "undeserving" (unemployed or sole parents) and illustrates the selective application of the ideas of new paternalism to target working-age welfare recipients. Unemployed or sole parents in New Zealand have been positioned within society as undeserving citizens since the early 1990s, when they were accused of making lifestyle choices to advantage themselves to the disadvantage of society in general. As noted by Soss, Fording and Schram, "poverty governance remains ... rooted in the meanings and practices of citizenship," and the price of 
citizenship now compels individuals to meet certain standards of behaviour, which includes employment, self-reliance and making good choices in life. ${ }^{102}$ This is notwithstanding their circumstances, options, capacities or preferences.

\section{Conclusion}

The analytical frames of neoliberalism and paternalism, together with the use of the language of these frames, has been used to show the punitive treatment of those who are poorest in New Zealand and to suggest that a change of framework is needed if meaningful change is to result. While many would consider that society has progressed beyond the "neoliberal/paternalistic experiment," this study shows that neoliberal paternalistic logics continue to provide a strong explanatory framework for the governance of poverty outlined throughout this article. As noted by Soss, Fording and Schram, a citizen who is not working and/or is reliant on the state for financial support is portrayed as a "civic failure," "not just for dodging her own obligation to work, but also for presenting her children with a bad role model, exposing them to shame, and failing to go out and provide for their needs." 103 The consequences of such civic failure in New Zealand are evident in the examples provided throughout this study.

George Orwell was the first to record that all may be equal, but some will be more equal than others. ${ }^{104}$ The illustrations provided in this article serve to highlight that all are not equal in New Zealand. Moreover, the study draws attention to the regulatory practices that serve to reinforce the dominant narrative about the role in society of those on welfare. Those who are working are the desirable citizens, and much of the current welfare provision is focused on creating such desirable citizens and punishing those who do not comply with the imposed rules. Welfare has moved from being a universal provision based on need to a provision conditional on compliant behaviour.

The new paternalism framework emphasises the increased use of rules and penalties to ensure individuals are compliant. The neoliberalist perspective highlights how market logics have been (re)created to emphasise the roles of a "good citizen" in society. Individualism is valued and personal responsibility for both the past and the present is desired. Both frameworks show how recent reforms to the welfare system facilitate greater punitive treatment of those who are noncompliant within the welfare system. However, it is in contrast to taxpayers that the punitive nature of recent reforms becomes most visible. Taxpayers who are not compliant are not subject to a similar level of surveillance or penalty as those on welfare, despite the outcome of tax noncompliance having an identical impact on society.

${ }^{1}$ Definition amended from that used in the European Commission White Paper on Governance, European Commission, European Governance - A White Paper (Brussels: Commission of the European Communities, 2001).

${ }^{2}$ Edwin H. Sutherland, "White-Collar Criminality," American Sociological Review 5, no. 1 (1940):112; Edwin H. Sutherland, "Is 'White-Collar Crime' Crime?" American Sociological Review 10, no. 2 (1944) 132-39; Edwin H. Sutherland, White Collar Crime (New York: Holt, Rinehart and Winston, 1949).

${ }^{3}$ Sutherland, White Collar Crime, 8. 
${ }^{4}$ Dee Cook, Criminal and Social Justice (London: Sage Publications, 2006); Hazell Croall, Understanding White Collar Crime (Buckingham: Open University Press, 2001); Kaaryn Gustafson, "The Criminalization of Poverty," Journal of Criminal Law \& Criminology 99, no. 3 (2009): 643716; John Hagan, Ilene H. Nagel and Celesta Albonetti, "The Differential Sentencing of White-Collar Offenders in Ten Federal District Courts," American Sociological Association 45, no. 5 (1980): 80220; Barbara Hudson, Penal Policy and Social Justice (Basingstoke: MacMillan Press, 1993); Jeffrey Reiman and Paul Leighton, The Rich get Richer and the Poor get Prison: Ideology, Class, and Criminal Justice, 10th Edition (Boston: Pearson, 2013); Laureen Snider, "Traditional and Corporate Theft: A Comparison of Sanctions," in White-Collar and Economic Crime, ed. Peter Whitman and Timothy Dailey (Lexington: Lexington Books, 1982); Loic Wacquant, Punishing the Poor: The Neoliberal Government of Social Insecurity (Durham: Duke University Press, 2009); David Weisburd, Stanton Wheeler, Elin Waring and Nancy Bode, Crimes of the Middle Classes: WhiteCollar Offenders in the Federal Courts (New Haven: Yale University Press, 1991).

${ }^{5}$ Gregory Marston and Tamara Walsh, "A Case of Misrepresentation: Social Security Fraud and the Criminal Justice System in Australia," Griffith Law Review 17, no. 1 (2008): 292.

${ }^{6}$ Weisburd, Wheeler, Waring and Bode, Crimes of the Middle Classes, 7.

${ }^{7}$ Lisa Marriott, "Justice and the Justice System: A Comparison of Tax Evasion and Welfare Fraud in Australasia," Griffith Law Review 22, no. 2 (2014): 403-29.

${ }^{8}$ Paul Wilson, John Walker, and Satyanshu Mukherjee, How the Public Sees Crime: An Australian Survey, Trends \& Issues in Crime and Criminal Justice no. 2 (Canberra: Australian Institute of Criminology, 1986): 1-6; M.D.R. Evans and Jonathan Kelley, "Are Tax Cheating and Welfare Fraud Wrong? Public Opinion in 29 Nations," Australian Social Monitor 3, no. 4 (2001): 93-102; Marta Orviska and John Hudson, "Tax Evasion, Civic Duty and the Law Abiding Citizen," European Journal of Political Economy 19 (2002): 82-103; Peter H. Rossi, Emily Waite, Christine E. Bose and Richard E. Berk, "The Seriousness of Crimes: Normative Structure and Individual Differences" American Sociological Review 39, no. 2 (1973): 224-37; Geoffrey Smith, Mark Button, Les Johnston and Kwabena Frimpong, Studying Fraud as White Collar Crime (Basingstoke: Palgrave MacMillan, 2011).

${ }^{9}$ Wilson, Walker, and Mukherjee, How the Public Sees Crime.

${ }^{10}$ John Walker, Mark Collins and Paul Wilson, How the Public Sees Sentencing: An Australian Survey, Trends and Issues in Crime and Criminal Justice no. 4 (Canberra: Australian Institute of Criminology, 1987).

${ }^{11}$ Ruth McIntosh and John Veal, "Tax Evasion and New Zealanders' Attitudes Towards It," New Zealand Journal of Taxation Law and Policy 7 (2001):80-110; Ranjana Gupta, "Perceptions of Tax Evasion as a Crime: Evidence from New Zealand," New Zealand Journal of Taxation Law and Policy 12 (2006):199-219.

${ }^{12}$ F.T. Cullen, B.G. Link and C.W. Polanzi, "The Seriousness of Crime Revisited," Criminology 20 (2005):83-102; Stuart Karlinsky, Hughlene Burton, and Cindy Blanthorne, "Perceptions of Tax Evasion as a Crime," eJournal of Tax Research 2 (2004)226-240.

${ }^{13}$ Lisa Marriott and Dalice Sim, "Tax Evasion and Welfare Fraud: Do punishments fit the crime or the perception of the crime?" Pacific Accounting Review 29 (2017):573-589, 582.

${ }^{14}$ Sanford F. Schram, Joe Soss, Richard C. Fording and Linda Houser, "Deciding to Discipline: Race, Choice, and Punishment at the Frontlines of Welfare Reform," American Sociological Review 74 (2009): 398-422.

${ }^{15}$ Robert Walker and Claire Collins, "Families of the Poor," in The Blackwell Companion to the Sociology of Families, ed. Jacqueline Scott, Judith Treas and Martin Richards (London: Blackwell Publishing, 2004), 191.

${ }^{16}$ Joe Soss, Richard C. Fording, and Sanford F. Schram, "Governing the Poor: The Rise of the Neoliberal Paternalist State" (paper prepared for presentation at the 2009 Annual Meeting of the American Political Science Association, Toronto, Canada), 2.

Journal of New Zealand Studies NS27 (2018), 110-129

https://doi.org/10.26686/jnzs.v0iNS27.5179 
http://stage.centerforthehumanities.org/sites/default/files/media/Governing\%20the\%20Poor SossFord ingSchram_2009.pdf

${ }^{17}$ Wendy Larner, "Neo-liberalism, Policy, Ideology, Governmentality," Studies in Political Economy 63, no. 1 (2000): 12.

${ }^{18}$ Ibid.

${ }^{19}$ Nikolas Rose and Peter Miller, "Political Power beyond the State: Problematics of Government," The British Journal of Sociology (2010): 272.

${ }^{20}$ Soss, Fording and Schram, "Governing the Poor," 4.

${ }^{21}$ Ibid.

${ }^{22}$ John Morrow, "Neo-liberalism," in New Zealand: Government and Politics, 3rd Edition, ed.

Raymond Miller (Oxford: Oxford University Press, 2003), 561.

${ }^{23}$ Ibid.

${ }^{24}$ Rose and Miller, Political Power, 289.

${ }^{25}$ Nigel Haworth, "Neo-liberalism, Economic Internationalisation and the Contemporary State in New Zealand," in Leap into the Dark: The Changing Role of the State in New Zealand since 1984, ed.

Andrew Sharp (Auckland: Auckland University Press, 1994), 27.

${ }^{26}$ Morrow, "Neo-liberalism."

${ }^{27}$ Morrow, "Neo-liberalism," 557; Rose and Miller, Political Power, 295.

${ }^{28}$ Ruth Richardson, Making a Difference (Christchurch: Shoal Bay Press, 1995), 207-08.

${ }^{29}$ The Domestic Purposes Benefit, now called Sole Parent Support, provided financial support for single parents with dependent children.

${ }^{30}$ Richardson, Making a Difference, 209-10. The Domestic Purposes Benefit, now called Sole Parent Support, provided financial support for single parents with dependent children.

${ }^{31}$ Morrow, "Neo-liberalism," 558.

${ }^{32}$ Vishanthie Sewpaul, "Neoliberalism," in International Encyclopedia of the Social \& Behavioral Sciences, 2nd Edition, 16 (2015): 463.

${ }^{33}$ Wendy Brown, "American Nightmare: Neoliberalism, Neoconservatism, and De-democratization," Political Theory 34, no. 6 (2006): 694.

${ }^{34}$ Ministry of Health, Social Bonds - Progress to Date, Available at: https://www.health.govt.nz/ourwork/preventative-health-wellness/social-bonds-new-zealand-pilot/social-bonds-progress-date,

Retrieved 17 June 2018.

${ }^{35}$ Ministry of Social Development, Strategic Intentions 2015-2019. https://www.msd.govt.nz/aboutmsd-and-our-work/publications-resources/corporate/statement-of-intent/index.html

${ }^{36}$ Ibid.

${ }^{37}$ Christine Cooper, Cameron Graham and Darlene Himick, "Social Impact Bonds: The Securitization of the Homeless," Accounting, Organizations and Society 55 (2016): 65.

${ }^{38}$ Ministry of Social Development, The Investment Approach: Benefit System Performance Reports, Available at: https://www.msd.govt.nz/about-msd-and-our-work/publicationsresources/evaluation/investment-approach/index.html, Retrieved 14 June 2018.

${ }^{39}$ See, for example, page 4 of the 2016 Benefit System Performance Report. H. Raubal, E. Judd and D. Stoner, "2016 Benefit System Performance Report", (Ministry of Social Development, 2017).

${ }^{40}$ Christine Cooper, Cameron Graham and Brendan O’Dwyer, "Social Impact Bonds: Can Private Finance Rescue Public Programs?" in Accounting, Organizations and Society Conference on Performing Business and Social Innovation through Accounting Inscriptions, September 2013. http://strathprints.strath.ac.uk/45845/

${ }^{41}$ Soss, Fording and Schram, "Governing the Poor," 4.

${ }^{42}$ Ibid.

${ }^{43}$ Lawrence M. Mead, "The Rise of Paternalism," in The New Paternalism: Supervisory Approaches to Poverty, ed. Lawrence M. Mead (Washington, D.C.: Brookings Institution Press, 1997), 2. ${ }^{44}$ Ibid.

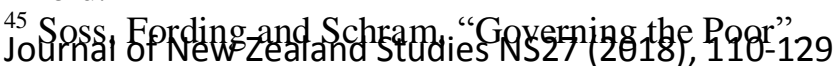


${ }^{46}$ Lawrence M. Mead, Beyond Entitlement: The Social Obligations of Citizenship (New York: The Free Press, 1997).

${ }^{47}$ Ibid, $10-11$.

${ }^{48}$ Ibid.

${ }^{49}$ Soss, Fording and Schram, "Governing the Poor," 6.

${ }^{50}$ Work and Income New Zealand. Obligations for Getting Jobseeker Support.

http://www.workandincome.govt.nz/on-a-benefit/obligations-for-getting-jobseeker-support.html\#null

${ }^{51}$ Ibid.

${ }^{52}$ Ibid.

${ }^{53}$ Soss, Fording and Schram, "Governing the Poor," 6.

${ }^{54}$ A.G. Wilson, R.M. Houghton and R.K. Piper, Budgeting Assistance and Low Income Families: Changes in income and expenditure (Social Policy Agency, Ministry of Social Development, 1995)

${ }^{55}$ Vincent Dubois, "Towards a Critical Policy Ethnography: Lessons from Fieldwork on Welfare

Control in France," Critical Policy Studies 3, no. 2 (2009): 221-39.

${ }^{56}$ Ministry of Social Development, Annual Report 2014/15, 26.

https://www.msd.govt.nz/documents/about-msd-and-our-work/publications-

resources/corporate/annual-report/2014-2015/annual-report-2014-2015.pdf

${ }^{57}$ Ibid.

${ }^{58}$ Susan St John, Catriona MacLennan, Hannah Anderson and Rebecca Fountain, The Complexities of "Relationship" in the Welfare System and the Consequences for Children (Child Poverty Action

Group Background Paper, 2014).

http://www.cpag.org.nz/assets/141204CPAG\%20Welfare\%20System\%20final.pdf

${ }^{59}$ Work and Income New Zealand. Relationship Status Verification Form, V24W-JUL2013, 3.

http://www.workandincome.govt.nz/documents/forms/relationship-status-verification-form.pdf

${ }^{60}$ Loic Wacquant, "The Penalisation of Poverty and the Rise of Neo-Liberalism," European Journal

on Criminal Policy and Research 9 (2001): 401.

${ }^{61}$ Ibid.

${ }^{62}$ Gustafson, The Criminalization of Poverty.

${ }^{63}$ Dubois, Towards a Critical Policy Ethnography; F. F. Piven and R. A. Cloward, Regulating the

Poor: The Functions of Public Welfare (New York: Vintage Books, 1971); Soss, Fording and Schram

"Governing the Poor."

${ }^{64}$ Fewer than $20 \%$ percent of workers in New Zealand belong to a union.

${ }^{65}$ Ministry of Social Development, Annual Report 2013/14.

https://www.msd.govt.nz/documents/about-msd-and-our-work/publications-

resources/corporate/annual-report/2014/annual-report-2013-2014.pdf.

${ }^{66}$ Data provided under the Official Information Act 1982, 3 September, 2012.

${ }^{67}$ Ministry of Social Development, Annual Report 2014/15 and Marriott, "Justice and the Justice System."

${ }^{68}$ Marriott, "Justice and the Justice System."

${ }^{69}$ The author was approached in writing by Wayne Patterson while he was incarcerated in Whanganui Prison in New Zealand; all comments made by Patterson are separately validated in media commentary pertaining to his offending.

${ }^{70}$ Brendan Manning, "Country’s worst benefit fraudster loses $\$ 3.3 \mathrm{~m}$ in Apple shares," New Zealand Herald. http://www.nzherald.co.nz/business/news/article.cfm?c_id=3\&objectid=11360620, Accessed 1 July 2016.

${ }^{71}$ Inland Revenue, Media Release. 24 June 2015. Inland Revenue welcomes Alex Swney sentence of five years seven months in jail for tax evasion. http://www.ird.govt.nz/aboutir/media-centre/mediareleases/2015/media-release-2015-06-24.html, Accessed 1 July 2016.

${ }^{72}$ Office of the Associate Minister for Social Development, "Welfare Debt Recovery," Cabinet Social Policy Committee, Cabinet Paper, 2012, Available at: https://www.msd.govt.nz/documents/about- 128 Journal of New Zealand Studies NS27 (2018), 110-129

https://doi.org/10.26686/jnzs.v0iNS27.5179 
msd-and-our-work/work-programmes/welfare-fraud/welfare-debt-recovery.pdf, retrieved 23 July 2016.

${ }^{73}$ Data provided under the Official Information Act 1982, 9 May 2013.

${ }^{74}$ Data provided under the Official Information Act 1982, 30 November 2017.

${ }^{75}$ Lisa Marriott, "Unpaid Tax and Overpaid Welfare: A comparison of the debt recovery approaches in New Zealand," New Zealand Journal of Taxation Law and Policy 20 (2014):46-70.

${ }^{76}$ Data provided under the Official Information Act 1982, 9 May 2013.

${ }^{77}$ Ministry of Social Development, Annual Report 2014/15.

${ }^{78}$ Relationship fraud typically arises when one person fails to declare that they are in a relationship or fails to advise the Ministry of Social Development when their relationship status changes.

${ }^{79}$ Correspondence from the Ministry of Social Development, 7 September 2016.

${ }^{80}$ Tax Administration Act 1994 (TAA), s 157.

${ }^{81}$ Data provided under the Official Information Act 1982, 12 July 2016.

${ }^{82}$ Provisions do exist under s 183 of the Child Support Act. However, this is outside the scope of the current discussion, which relates to core tax payments and welfare expenditures.

${ }^{83}$ Ministry of Social Development, Annual Report 2014/15.

${ }^{84}$ Data provided under the Official Information Act 1982, 7 September 2016.

${ }^{85}$ Data provided under the Official Information Act 1982, 7 September 2016. The deduction notice figures are not necessarily the same as recoveries actually received, as deductions may be returned where insufficient funds are held by banks or individuals are no longer employed.

${ }^{86}$ TAA, s 6A(3).

${ }^{87}$ TAA, s 176(2)(a)-(b).

${ }^{88}$ TAA, s 177.

${ }^{89}$ Inland Revenue Department, Standard Practice Statement SPS 06/02, Writing Off Outstanding Tax, para. 11, 75. https://www.ird.govt.nz/technical-tax/standard-practice/withdrawn/sps-06-02outstanding-tax.html

${ }^{90}$ TAA, s $177 \mathrm{~A}(2)$.

${ }^{91}$ TAA, s $177 \mathrm{~A}(3)$.

${ }^{92}$ Office of the Associate Minister for Social Development, "Welfare Debt Recovery," 3.

${ }^{93}$ Ibid, 2.

${ }^{94}$ Ibid, 3.

${ }^{95}$ Schram, Soss, Fording and Houser, "Deciding to Discipline," 398.

${ }^{96}$ Sanford F. Schram, Joe Soss, Linda Houser and Richard C. Fording, "The Third Level of US Welfare Reform: Governmentality under Neoliberal Paternalism," Citizenship Studies 14, no. 6 (2010): 739-54, 739.

${ }^{97}$ Ministry of Social Development, Annual Report 2014/15.

${ }^{98}$ In 1972, the Royal Commission of Inquiry into Social Security (also known as the McCarthy Commission) offered four objectives of the welfare system, the second of which was 'to belong and participate, i.e. to meet and mix with other New Zealanders as a full member of the community'. This was the option that was selected as the objective for welfare benefits, which were subsequently recommended to be 80 per cent of the wage of a builders' labourer. Royal Commission of Inquiry on Social Security, Social Security in New Zealand: Report of the Royal Commission of Inquiry (Wellington, Government Printer, 1972).

${ }^{99}$ Schram, Soss, Houser and Fording, "Third Level of US Welfare Reform," 740.

${ }^{100}$ Loic Wacquant, "Crafting the Neoliberal State: Workfare, Prisonfare, and Social Insecurity," Sociological Forum 25, no. 2 (2010): 197-220.

${ }^{101}$ Wacquant, Punishing the Poor, xvi.

${ }^{102}$ Soss, Fording and Schram, "Governing the Poor."

${ }^{103}$ Soss, Fording and Schram, "Governing the Poor," 22.

${ }^{104}$ George Orwell, Animal Farm (London: Secker and Warburg, 1945).

Journal of New Zealand Studies NS27 (2018), 110-129

https://doi.org/10.26686/jnzs.v0iNS27.5179 